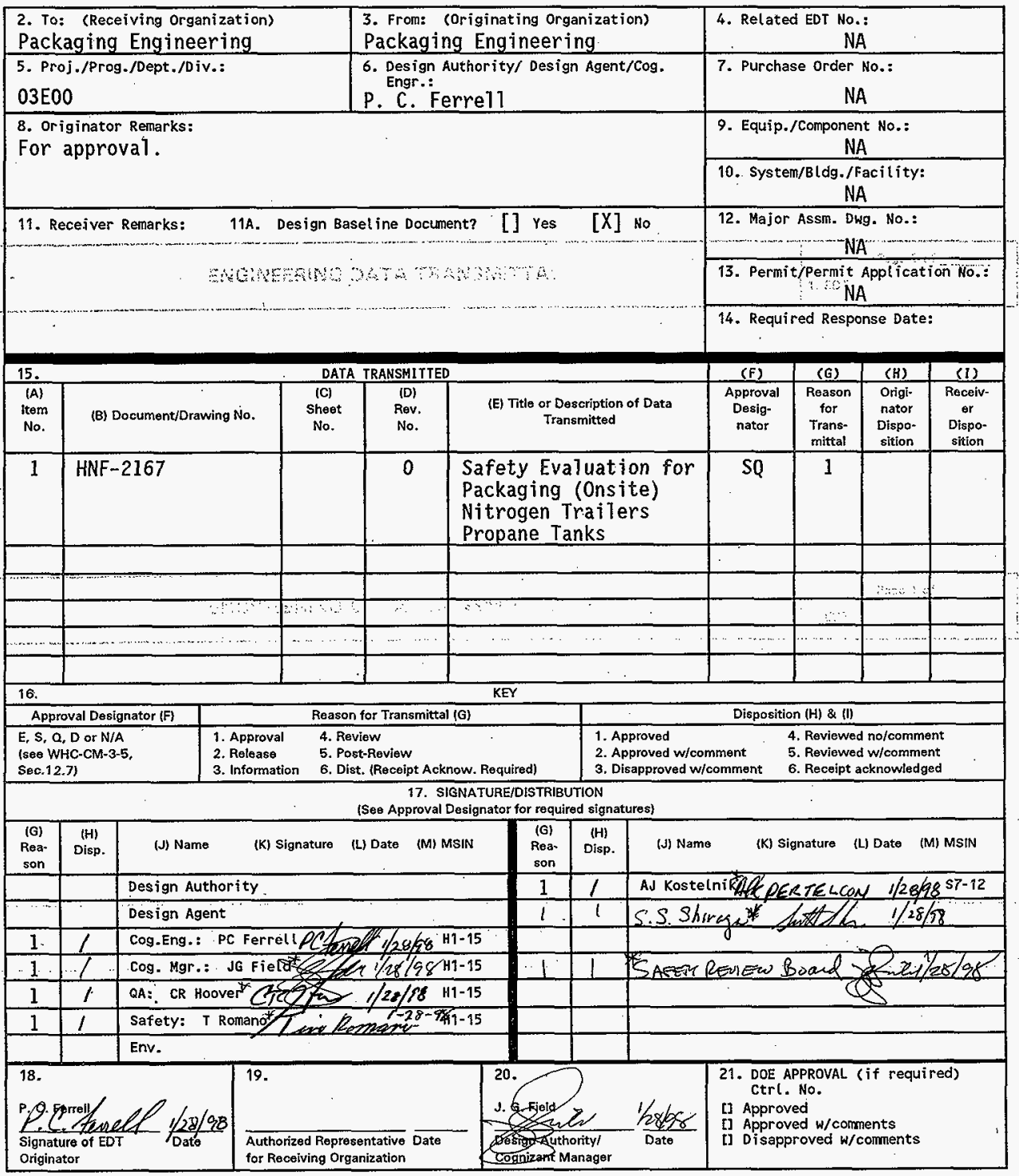


HNF-2167, Rev. 0

\title{
Safety Evaluation for Packaging (Onsite) Nitrogen Trailers Propane Tanks
}

\author{
P. C. Ferre1! \\ Waste Management Federal Services, Inc., Northwest Operations, \\ Richland, WA 99352 \\ U.S. Department of Energy Contract DE-AC06-96RL13200
}

EDT/ECN: EDT $621896 \quad$ UC: 513

Org Code: 03E00

B\&R Code: EW3120074 Total Pages: $\epsilon_{-3}-5$

Key Words: Safety Evaluation for Packaging, Onsite, Nitrogen Trailers Propane Tanks

Abstract: The purpose of the Safety Evaluation for Packaging (SEP) is the evaluation and authorization of the onsite transport of propane tanks that are mounted on the Lockheed Martin Hanford Corporation Characterization Project's nitrogen trailers. This SEP authorizes onsite transport of the nitrogen trailers, including the propane tanks, unti1 May 31, 1998.

TRADEMARK DISCLAIMER. Reference herein to any specific commercial product, process, or service by trade name, trademark, manufacturer, or otherwise, does not necessarily constitute or imply its endorsement, recommendation, or favoring by the United States Government or any agency thereof or its contractors or subcontractors.

Printed in the United States of America. To obtain copies of this document, contact: Document Control Services, P.O. Box 950, Maitstop H6-08, Richland WA 99352, Phone (509) 372-2420; Fax (509) 376-4989.
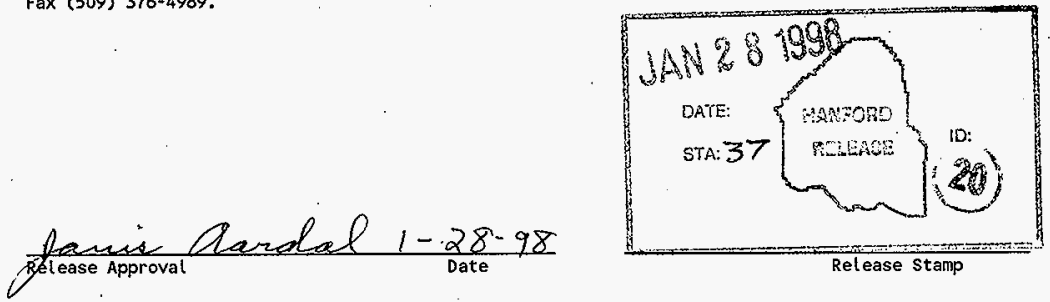
HNF-2167 Rev. 0

\section{SAFETY EVALUATION FOR PACKAGING (ONSITE) NITROGEN TRAILERS PROPANE TANKS}

The purpose of this Safety Evaluation for Packaging (SEP) is the evaluation and authorization of the onsite transport of the propane tanks that are mounted on the Lockheed Martin Hanford Corporation (LMHC) Characterization Project's nitrogen trailers. The three nitrogen trailers (HO-64-4966, HO-64-4968, and HO-64-5170) are rated for $1,361 \mathrm{~kg}(30,000 \mathrm{lb})$ and are equipped with tandem axles and pintel hitches. Permanently mounted on each trailer is a $5,678 \mathrm{~L}(1,500$ gal) cryogenic dewar that is filled with nitrogen, and a propane fired water bath vaporizer system, and a $454 \mathrm{~L}$ (120 gal) propane tank. The nitrogen trailer system is operated only when it is disconnected from the tow vehicle and is leveled and stabilized. When the trailers are transported, the propane tanks are isolated via closed supply valves.

The propane tanks are rated as storage containers for permanent installation on consumer premises. The propane tanks are not rated for normal transport and are not U.S. Department of Transportation (DOT) specification tanks. However, propane storage containers may be shipped under DOT regulations if they meet the requirements of 49 CFR 173.315(j). This regulation allows for the transport of propane tanks to and from the seller and consumer locations. The following is an evaluation of the propane tank's compliance with 49 CFR $173.315(j)$.

1. The tank must be constructed in compliance with the requirements of the American Society of Mechanical Engineers (ASME) Code and must be marked to indicate compliance in the manner specified by the respective code.

Evaluation: The attached data reports verify that the propane tanks meet this requirement. The tanks were fabricated and are currently marked in accordance with the ASME Code.

2. Each tank must be equipped with safety devices in compliance with the requirements for safety devices on containers as specified in the National Fire Protection Association (NFPA) pamphlet no. 58 (NFPA 1995).

Evaluation: Each propane tank has a safety valve that was installed by the manufacturers per the requirements of NFPA pamphlet no. 58 (NFPA 1995).

3. The containers shall be so braced or otherwise secured on the vehicle as to prevent relative motion while in transit. Valves or other fittings shall be adequately protected against injury during transport.

Evaluation: The propane tanks are bolted to the trailers and will not move relative to the surrounding equipment mounted on the trailers. A protective shroud is placed over most of the tank valving during transport. The propane tank is located between the nitrogen tank and the vaporizer system, and is inboard from the sides of each trailer. As such, the propane tanks are adequately protected and secured during transport.

4. Storage tanks of less than $473 \mathrm{~L}(125$ gal) may be shipped when charged with propane in compliance with DOT filling density.

Evaluation: This requirement will need to be verified prior to each shipment. 
HNF-2167 Rev. 0

Although the propane tanks meet the requirements of 49 CFR $173.315(j)$, they are not rated for continuous transport and are not DOT specification containers. As a result of this finding, this SEP was prepared to authorize interim use of the nitrogen trailers while a permanent solution can be developed.

This SEP authorizes onsite transport of the nitrogen trailers, including the propane tanks until May 31, 1998.

\section{REFERENCES}

49 CFR 173.315, 1996, "Compressed gases in cargo tanks and portable tanks," Code of Federal Regulations, as amended.

NFPA, 1995, Standard for the Storage and Handling of Liquefied Petroleum Gases, Pamphlet No. 58, prepared by the Technical Committee on Liquefied Petroleum Gases and acted on by National Fire Protection Association, Inc., at Fall Meeting, November 14-16, 1994 in Toronto, Ontario, Canada, issued February 7, 1995. 
ATTACHMENT: MANUFACTURER'S DATA REPORT FOR THE PROPANE TANKS.

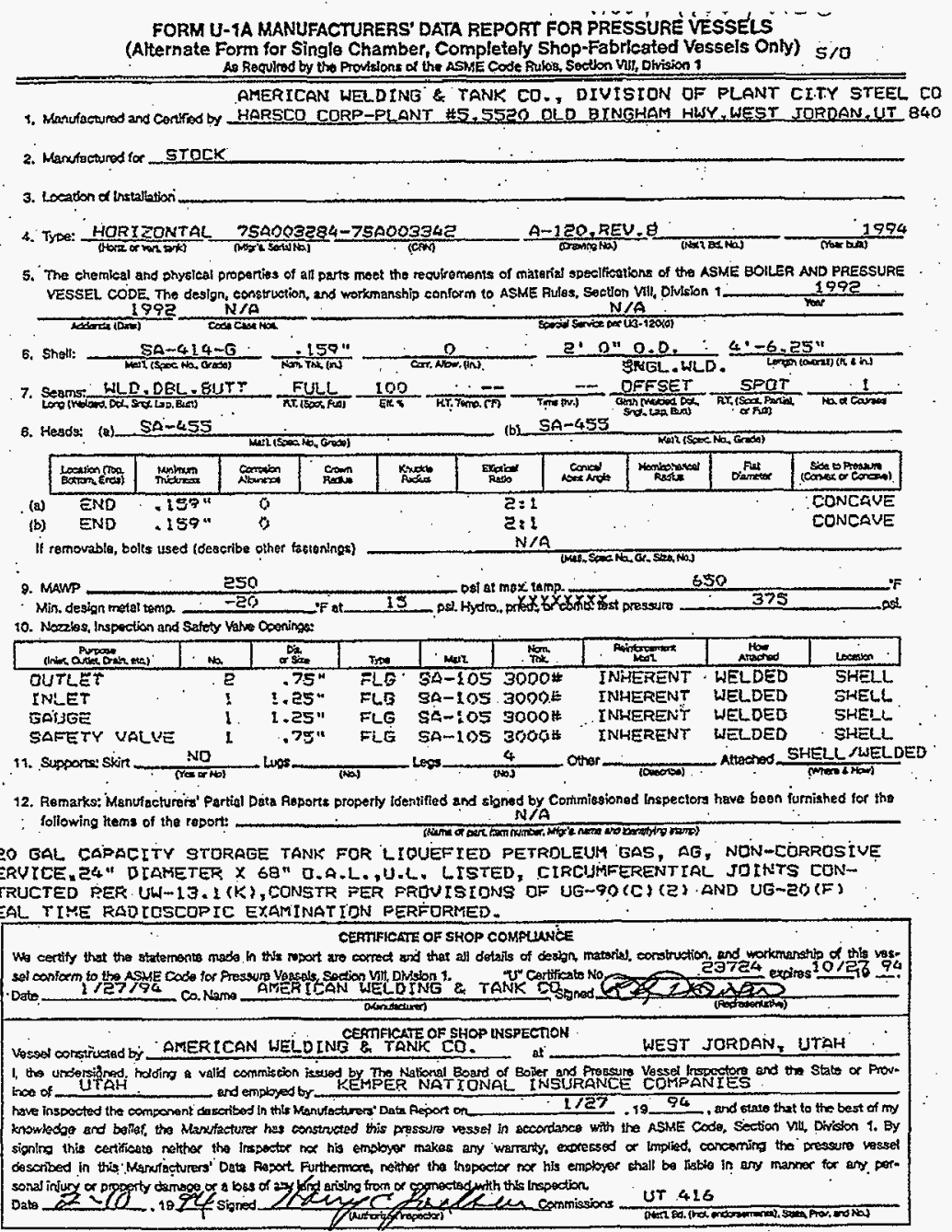


FORM U-1A MANUFACTURER'S DATA REPORT FOR PRESSURE VESSELS

(Allernaulve Form for Single Chamber, Completely Shop. Fabricatad Vessels Only)

As Fequired by the Provisions of the ASME Code Rules, Section Vili, Division i

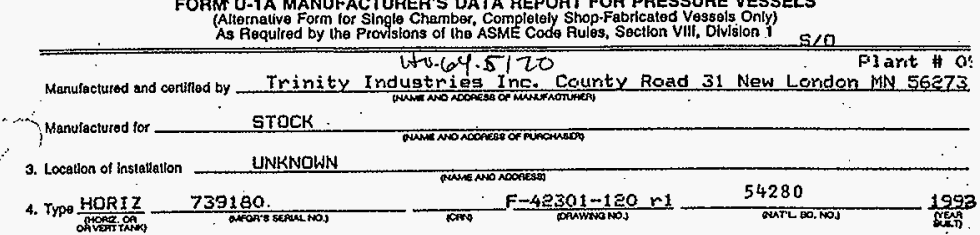

5. The chemical and physical properties of al perts moet the tequlrements of material specliceatlons of the ASME BOILER AND PRESSURE VESSEL CODE.

The deskgn, conslfuclion, and workmanshlp contorm to ASME Rutes, Section Vill, Division $1 \ldots 1989$

10 DEC/90

6. Shat: $\frac{\mathrm{SA} 414 \mathrm{G}}{\mathrm{M}}$

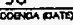

CODECASE NOOO.

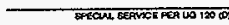

कात

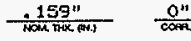

'-11. 696"

$-4^{\prime}-4.125^{\prime \prime}$

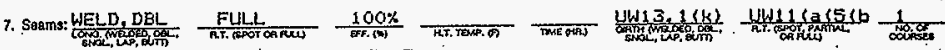

8. HaRds: (a) Matl. SA414E "(b) Matl.

Sog. Soams:

H.T.:

\begin{tabular}{|c|c|c|c|c|c|c|c|c|c|}
\hline 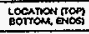 & 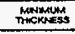 & 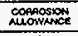 & $\begin{array}{c}\text { Chowh } \\
\text { Anous }\end{array}$ & $\begin{array}{l}\text { Kavory } \\
\text { Mow }\end{array}$ & $\frac{\text { aupmes }}{\text { ARto }}$ & 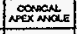 & 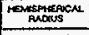 & $\begin{array}{l}\text { RAT } \\
\text { DWhETES }\end{array}$ & 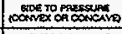 \\
\hline ENDS & $.15 B^{\prime \prime}$ & $0^{\prime \prime}$ & & & E:1 & & & & CONCAVE. \\
\hline & & & & & & & & & \\
\hline
\end{tabular}

Eff:

- If removable, botts used (describe other fastenings)

MAWP ESO

psi at Maximurin Temp. 1ES DEG. F

Min. desion motal temp - 20 DEG.F AT 250 psi test pressure 500 psi HYDROSTATIC

\begin{tabular}{|c|c|c|c|c|c|c|c|c|}
\hline mLY, , onfecer, onum & No. & $\operatorname{sem}_{\infty}$ & noe & men. & $\operatorname{mom}_{\mathrm{man}}$ & 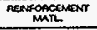 & ATACHOS & DOCATROA \\
\hline MULTYVLV & 1 & $.75^{n}$ & CPLG & 59105 & FLGD & & UW16.2(c) & \\
\hline FLOAT GA & 1 & 11 & CFLE & SA1CD & FLGD & & UW16.219 & \\
\hline$F I L L$ & 1 & $1.25^{\prime \prime}$ & CPLG & SA10 & FLSD & & Uhlegerd & \\
\hline RELIEF & $I$ & $.75 \%$ & CFLG & SA10S & FLGD & & HW16.erc & \\
\hline LIQ. PLUG & 1 & $.75^{11}$ & CFLG & SA10S & FLGD & & UL16.20 & \\
\hline LIQ UUT & 1 & $.75 \pi$ & CFLE & SA105 & FLGD & & LW16.2CO & \\
\hline
\end{tabular}

$\because$ Nozzlos, Inspection and seley valvo openings:

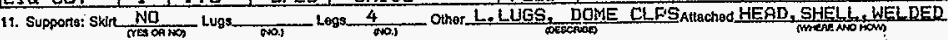

12. Remarks: Manulacturer's Partlat Data Reparts properly identified and signed by Comntestoned inspectors have been furnished for the following ilems of the teport:

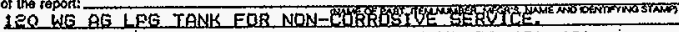

- CONSTRUCTED UNDER THE PROUISIONS OF US $\mathrm{GO}$ (C) (P).

LINE 3: MDMI /PSI EASED ON US $=20$ (F).

*REAL TIME RADIOSCQPIC EXAM. LOWG SEAM

\section{CERTIFICATE OF SHOP COUPLIANCE}

Wo cortly that the eletements mace in thls report are correct and thet ail detalls of deslgn, materiat, construction, and wotkmanship of this vessel contom

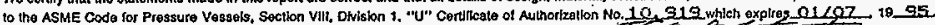

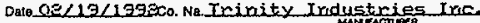

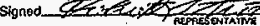

\section{CERTIFICATE OF SHOP INSPECTION}

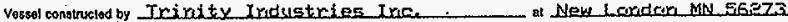

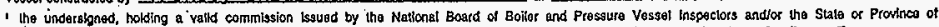
$\therefore$ Minnesata und employod by Western Naticonal Mutual Iras Co

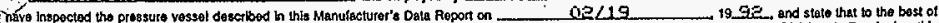

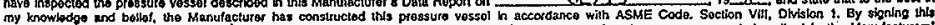

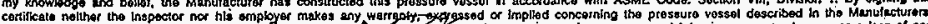

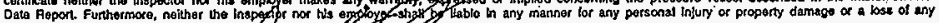

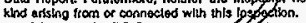

Deloe 119/1992 signed

TFt 4 TICON (T-20)

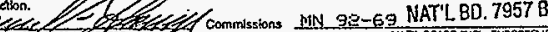

Z2.




\begin{tabular}{|c|c|c|c|c|c|}
\hline \multicolumn{6}{|c|}{ DISTRIBUTION SHEET } \\
\hline \multirow{2}{*}{$\begin{array}{l}\text { To } \\
\text { Distribution }\end{array}$} & \multirow{2}{*}{\multicolumn{3}{|c|}{$\begin{array}{l}\text { From } \\
\text { Packaging Engineering }\end{array}$}} & \multirow{2}{*}{\multicolumn{2}{|c|}{$\begin{array}{l}\text { Page } 1 \text { of } 1 \\
\text { Date } 01 / 27 / 98\end{array}$}} \\
\hline & & & & & \\
\hline \multicolumn{4}{|c|}{ Project Title/Work Order } & \multicolumn{2}{|c|}{ EDT No. 621896} \\
\hline \multicolumn{4}{|c|}{$\begin{array}{l}\text { Safety Evaluation for Packaging (Onsite) Nitrogen Trailers } \\
\text { Propane Tanks (HNF-2167, Rev. O) }\end{array}$} & \multicolumn{2}{|c|}{ ECN No. NA } \\
\hline Name & MSIN & $\begin{array}{l}\text { Text } \\
\text { With All } \\
\text { Attach. }\end{array}$ & Text Only & $\begin{array}{l}\text { Attach./ } \\
\text { Appendix } \\
\text { Only }\end{array}$ & $\begin{array}{l}\text { EDT/ECN } \\
\text { Only }\end{array}$ \\
\hline $\begin{array}{l}\text { R. M. Boger } \\
\text { J. E. Corbett } \\
\text { R. N. Dale } \\
\text { R. E. Falon } \\
\text { T. R. Farris } \\
\text { P. C. Ferrell } \\
\text { J. G. Field. } \\
\text { R. E. Freeman } \\
\text { C. R. Hoover } \\
\text { W. J. Kennedy } \\
\text { A. J. Kostelnik } \\
\text { J. S. Lee } \\
\text { T. Romano } \\
\text { J. S. Schofield } \\
\text { D. H. Shuford } \\
\text { J. F. Sickels } \\
\text { HNF-2167 File }\end{array}$ & $\begin{array}{l}S 7-12 \\
S 7-01 \\
S 7-12 \\
S 7-12 \\
S 7-12 \\
H 1-15 \\
H 1-15 \\
S 7-12 \\
H 1-15 \\
S 7-03 \\
S 7-12 \\
S 7-03 \\
H 1-15 \\
S 7-12 \\
S 7-01 \\
S 7-03 \\
H 1-15\end{array}$ & $\begin{array}{l}X \\
X \\
X \\
X \\
X \\
X \\
X \\
X \\
X \\
X \\
X \\
X \\
X \\
X \\
X \\
X \\
X \\
\end{array}$ & . & . & . \\
\hline Central Files & B1-07 & $x$ & & & \\
\hline
\end{tabular}

